\title{
Measuring the Intention to Return to a Foreign Tourism Destination in the Cases of Two Age Layers of Generation Y-a Logistic Regression- centred Approach. Evidence from Romania and South Africa
}

\author{
Tudor EDU \\ The Romanian - American University, Romania \\ tudoredu@yahoo.com \\ Iliuta Costel NEGRICEA \\ The Romanian - American University, Romania \\ negricea@yahoo.com \\ Norbert HAYDAM \\ Cape Peninsula University of Technology, South Africa \\ haydamn@cput.ac.za \\ Emanuela AVRAM \\ University of Bucharest, Romania \\ emanuela.maria@yahoo.it
}

\begin{abstract}
The paper focuses through a comprehensive qualitative and quantitative research on two age layers of Generation Y, unveiling important aspects about consumer behaviour constructs. Equal samples of 30 individuals in the qualitative study and 800 individuals in the quantitative one from Romania and South Africa were researched to explain the intention to return to a foreign destination based on the overall holiday experience and tourism motivation. The qualitative research was used to generate and tailor a battery of motivational variables to be used as independent variables in the quantitative study in logistic regression approaches for both countries. The findings display interesting realities about what Romanian and South African Generation Y individuals' (between 20- and 29-years old) value and desire when choosing a foreign tourism destination. Also, the proposed model can be easily replicated in other parts of the world or for other generational groups.
\end{abstract}

Keywords: Generation Y; tourism; intention to return; holiday experience; motivation;

JEL Codes: D12; M31; Z32;

DOI: http://doi.org/10.24818/ejis.2019.01

\section{Introduction}

Satisfaction and intention to repurchase have been widely covered in the consumer behaviour literature. Starting from a basic definition of consumer behaviour, emphasising the action and influences related to consumers prior, during and after a purchase (Strydom, 2004), satisfaction comes as a conclusion of an after purchasing evaluation and intention to repurchase as a probability of a future consumer behaviour process. Continuing on this line of thought, consumer satisfaction appraises the satisfaction level in comparison with a set of criteria (Cant et al., 2009) while intention to repurchase refers to the willingness of buying the same product in the future. Satisfaction and intention to repurchase put in a generational context provide significant insights as such studies are of crucial importance 
in understanding consumer behaviour coordinates. There are 6 generational groups based on the birth years, GI, Silent, Baby boomers, Generation, Generation Y and Generation Z (Pendergast, 2010) covering the time from the beginning of the 20th century until today, each being representative for a particular time frame, prompting distinct peculiarities when it comes to perceptions, attitudes and motives for buying products and services. These groups have been investigated for detailing and predicting consumer behaviour constituents pertaining to products and services, including tourism. According to Ratten and Tsiotsou (2010), generational studies will be at the forefront of future tourism consumer behaviour research. Most of the current studies focusing on tourism are comparisons between Generation Y and other generational groups (Li et al., 2013; Xiang et al., 2015; Huang and Petrick, 2010), very few focusing on Generation Y (Nusair et al., 2013; Muskat et al., 2014) and almost none focusing on the structures of Generation $\mathrm{Y}$ considering its vivid heterogeneity (Foscht et al., 2009; Paul, 2001).

Considering the lack of evidence about the tourism behaviour of different age layers of Generation Y, the purpose of this research is to provide insights about two very important features of tourist behaviour, satisfaction and intention to return, as they appear within Generation Y, proposing a model to be tested in Romania and South Africa.

\section{Satisfaction and Intention to Return in Tourism}

Satisfaction was grounded in theory in several ways, some of the posited ideas being adapted and used in tourism as well. Briefly presented, satisfaction can be assessed based on comparisons between the actual purchase and expectations formed from previous purchases or collected information (Oliver, 1980), based on comparisons between the actual purchase and pre-set standards (Latour and Peat, 1979), based on the effect-effort relationship (Oliver and Swan, 1989) or just based on the performance of the purchase itself (Tse and Wilton, 1988). All these theories have been used in tourism to explain satisfaction. In the present study, the purchase performance-based satisfaction was considered as the goal was to assess satisfaction based on the holiday experience approached globally. The extant tourism literature displays significant evidence pertaining to the use of this approach. According to Assaker et al. (2011) and Moutinho (1987) satisfaction should be assessed rather based on the overall experience at the destination while Spreng et al. (1996) posit that satisfaction is the outcome of the overall experience. Kozak (2001) underlines the importance of determining satisfaction based just on the performance approach, stating that holiday experiences are the most important determinants of satisfaction. Continuing from this angle, an overall dissatisfying experience would lead to a low propensity of repurchase (adaptation from Oliver, 1980), thus satisfaction placed in a tourism context is a highly important influencer when it comes to the returning intention (Valle et al., 2006). Anyway, a very important peculiarity in tourism is that revisits are very seldom exactly replicated (Lehto et al., 2004). The extant literature reveals instances in which the intention to return is approached with a focus on market segments or tourist profiles (Opperman, 2000; Jang and Feng, 2007), travel recency and frequency corroborated with the money spent at destinations (Hughes, 1995), destination attribute performance (Baker and Crompton, 2000) or tourism motivation (Yoon and Uysal, 2005). Also, Chen and Tsai (2007) speak of a relationship between travelling intentions and a series of determinants while Chen and Chen (2010) posit a model in which intention (seen as a possibility to revisit or recommend) is dependent on satisfaction, experience quality and perceived value. 
Intention to return in this study is determined in two ways, one based on satisfaction which is expressed as the overall holiday experience, and the other one based on motivational factors for returning, offering, thus, two different perspectives. Motivation is widely covered in the tourism literature with the push-pull (motivation) dichotomy (Dann, 1977) having a wide exposure. The push motivational variables or internal motivational factors are related to the tourist while the pull variables or the external motivational factors are connected to the destination (Crompton, 1979). To provide a general perspective of these two types of tourism motivational factors, a few works are detailed. Crompton (1979) describes the push motivational group as comprising seven variables (escaping from a familiar environment, exploration and evaluation of self, relaxation, prestige, regression, enhancement of kinship relationships and facilitation of social interactions), while Uysal and Hagen (1993) refer to escape, rest and relaxation, prestige, health, fitness, adventure and family and Kozak (2002) proposes getting away from the city life. Within the pull motivational group, Uysal and Hagan (1993) included climate, scenery, historic sites, sunshine, beaches, snow, cultural events and recreational opportunities, while Crompton (1979) includes novelty and education and Chon (1991) includes food. Based on a thorough review of the tourism literature on motivation, a list with 33 push (internal) and pull (external) motivational variables was drafted and displayed in Table 2 together with the sources to be further used in building the conceptual model of the present research.

\section{Generation Y- Main Descriptive Facts}

It is quite difficult to establish the exact time interval of Generation $\mathrm{Y}$ considering the plethora of studies proposing different time frames based on birth years, for example 19771994 (Sheahan, 2005), 1978-2002 (Sommer and Trudy, 2006), 1980-2000 (Erickson, 2008) or 1982-2002 (McCrindle, 2003). However, it is posited that Generation Y is heterogeneous (Foscht et al., 2009), comprising 3 distinct groups based on birth patterns (Paul, 2001), group no. 1, including everyone born up to 1983, group no. 2, including the individuals born between 1984 and 1989 and group no. 3, including everyone born after 1990.

Generation $\mathrm{Y}$ is marked by significant social and ethnic diversities (Howe and Strauss, 2000) which, corroborated with its heterogeneity, make its treatment as a single entity challenging. However, the Generation Y members are well connected to the worldwide realities (Hurst and Good, 2009), are generally and technologically better educated than other generations and are confident (Pendergast, 2010). They use technology very often for interaction purposes and entertainment (Bolton et al., 2013) and are very communicative (Jorgensen, 2003). The Generation Y-ers are very close to their parents (Eisner, 2005), being active in household decisions, and, because of this strong connection, they move out from their parents' home late (Szamosi, 2006). As consumers, the Generation Y members look for new experiences (Jorgensen, 2003), excitement and entertainment (Muskat et al., 2014). They would select products in many instances based on emotions and stores based on rational reasons (Parment, 2013). According to Noble et al. (2009), they value brands for identity and comfort, but loyalty is not always certain.

Narrowing down to tourism, Generation $\mathrm{Y}$ was seldom approached on its own in travel behaviour studies (Huang and Petrick, 2010). In most cases, this generational group was studied in comparative analyses with other generational groups. According to Glover (2010) and $\mathrm{Li}$ et al. (2013), the Generation Y members like to travel abroad, being interested in visiting new (Benckendorff and Moscardo, 2010) and unique venues 
(Richards, 2007). They like beaches, theme parks, sports, weather, entertainment venues and shopping facilities (Huang and Petrick, 2010). Other destination attributes considered important by Generation Y-ers are safety, value for money, easy access, domestic transportation, food, accommodation, scenery, cleanliness and services (Li et al., 2013). The Generation Y members like to travel for reasons pertaining to shopping, entertainment, exploring the environment ( $\mathrm{Li}$ et al., 2013), for excitement and to rest and relax (Benckendorff and Moscardo, 2010). They are very involved in travel planning (Kim et al., 2015), informing themselves thoroughly about the destinations (Richards, 2007; Benckendorff and Moscardo, 2010), using mainly online sources (Pearce and Coghlan, 2008), TV and radio broadcasts and personal sources, such as family and friends (Huang and Petrick, 2010). However, these tourist behaviour traits should be treated with the appropriate caution considering the heterogeneity of this generational group. Based on Glover (2010), from a behavioural perspective, one individual's attitudes influence the preferences and behaviour leading to various market segments within a generational group.

\section{Methodology}

\subsection{Research design}

The research methodology used in this paper entails two steps, a qualitative one and a subsequent quantitative one. The qualitative methodology was used to tailor the independent variables drawn from the tourism literature to the peculiarities of the two age Generation Y groups from Romania and South Africa. In order to accomplish this task, based on Kozak (2001), 30 semi-structured in-depth interviews were conducted both in Romania and South Africa with Generation Y individuals asking them to choose from the 33 motivational variables compiled from literature and presented in Table 2 the variables that are important when considering to return to a destination allowing, also, the respondents to express their thoughts about the presented variables and to mention new variables. Only the variables mentioned by both samples were retained in the model, the final stage being presented in the Table 2.

Continuing with the quantitative research, semantic differential scales with 5 levels (from 'very satisfied' to 'very dissatisfied' for the overall holiday experience and from 'very important' to 'not important at all' for motivational variables and intention to return) were employed for collecting data (Kozak and Rimmington, 2000; Chen and Chen, 2010). For ease of measuring the respondents were asked to refer only to their last tourist experience in a foreign country. For a comprehensive understanding of the implications and a thorough perspective of the model, forward, backward and enter logistic regressions were performed, preserving the variants with the largest number of predictors for which the HosmerLemeshow test for the goodness of fit displayed a significance value greater than 0.05 .

The logistic regression method was used for two main reasons. The first reason is that normality is not an assumption to be met and the second reason is that it allows for item selection, being, thus, an alternative to factor analysis. The dependent variable was converted into categorical variables with two categories by combining the positive levels of the semantic differential scale into one category and the negative and neutral ones into another category (Chon, 1991; Allison, 2008). In the case of "Intention to return to the foreign destination" the positive levels were combined into a category named "Yes" and the negative and neutral levels into a category named "No". As zero frequencies were encountered in at least one category of some independent variables, these variables were 
transformed into categorical variables by combining the negative and neutral levels of the semantic differential scales into one category named 'unimportant' and the positive levels into one category named 'important' (Allison, 2008).

\subsection{Model presentation}

This paper investigates two age layers within Generation Y from Romania and South Africa, one layer between 20 and 24 years old and the other layer including individuals between 25 and 29 years old, pursuing to explain, based on the overall holiday experience had in a foreign destination (as a measure of satisfaction and seen as the past behaviour) and motivation to travel, the intention to return to the respective foreign destination (seen as the future behaviour).

The holiday experience had in a foreign destination is approached globally using one question and the intention to return to the respective foreign destination is assessed based on motivation and sociodemographic variables (age, gender, education, marital status and source of funding the trip) plus based on holiday experience on the other side.

Thus, a conceptual model is proposed to be tested, comprising two sections. The first section of the model intends to measure the tourist's intention to return based on motivation and five socio-demographic variables. The 33 motivational variables grouped in external (pull) motivation and internal (push) motivation and compiled from literature in Table 2 will be considered as independent variables being subsequently tailored to the peculiarities of two Generation Y groups from Romania and South Africa. Five socio-demographic variables are considered in the model for both dependent variables (holiday experience and intention to return), age, gender, education, marital status and source of funding the trip.

Sociodemographic variables have been used as independent variables in previous tourism studies. For example, age is posited as a factor in choosing destination attributes (Weaver et al., 1994), education as a variable influencing the decision to travel (Zimmer et al., 1995) while age, gender and education are considered suitable predictors of the duration of stay (Machado, 2010). The remaining two demographic variables will give weight to the model, revealing the impact of the family structure and financial side on satisfaction and intention to return. The second section measures the impact of the tourist's holiday experience on his/her intention to return, giving a second perspective of measurement of the returning intention.

\subsection{Research hypotheses}

The purpose of this study is to model the relationship between the holiday experience in a foreign destination and the intention to return to the respective foreign destination using two sub-models. For ease of measuring the respondents were asked to refer only to their last tourist experience in a foreign country. Based on logistic regression, two types of relationship can be tested between the dependent and independent variables: direct (same direction evolution or increase-increase relationship) and inverse (opposite direction evolution or increase-decrease relationship). The first section of the model is represented by the intention to return to the foreign destination, referred to as the future behaviour, being explained based on pull factors (pertaining to the tourist) and push variables (pertaining to the destination) and 5 demographic variables and, thus, 7 hypotheses being drafted:

H1. There is a direct relationship between the intention to return to the foreign destination and the external motivation (pull); 
$\mathrm{H} 2$. There is a direct relationship between the intention to return to the foreign destination and the internal motivation (push);

H3. Men are more likely to return to the foreign destination than women;

H4. The $20-24$ years old individuals are more likely to return to the foreign destination than the ones aged between 25 and 29 years old;

H5. The individuals funding the trip with their own sources are more likely to return to the foreign destination than the ones funding with other sources;

H6. The married individuals are more likely to return to the destination than the unmarried ones;

H7. The individuals with a high school level and below are less likely to return to the destination than the ones with a post high school level;

H8. There is a direct relationship between the intention to return to the foreign destination and the overall holiday experience;

\subsection{The sampling procedure}

The sampling procedure entailed two approaches, one for the qualitative study and another one for the quantitative one. In the qualitative study, a sample of 30 individuals was used based on a quota sampling procedure, resembling the population structure in Romania and South Africa for age (using two groups: 20-24 years old and 25-29 years old) and gender (STATS SA, 2014; National Institute of Statistics, 2015). Thus, the sample for each country included 8 men between 20 and 24 years old, 7 women between 20 and 24 years old and 8 men between 25 and 29 years old and 7 women between 25 and 29 years old. To be included in the sample, each individual should have travelled abroad at least once in the past 5 years.

In the quantitative study, a sample of 800 individuals per each country was used based on a random multiple-layer sampling procedure using age (two groups: 20-24 years old and 25-29 years old) and gender as sampling criteria. Again, to be included in the sample, the individual should have travelled abroad at least once in the past five years. Also, in data collection a systematic sampling procedure was used (every other $10^{\text {th }}$ individual being stopped for completing the questionnaire). The sample structures of the quantitative study for both countries are presented in Table 1.

Table 1. Sample structure for the selected countries

\begin{tabular}{|l|c|c|c|c|}
\hline \multicolumn{1}{|c|}{ Age } & \multicolumn{2}{|c|}{ South Africa } & \multicolumn{2}{c|}{ Romania } \\
\hline \multicolumn{1}{|c|}{ Gender } & Male & Female & Male & Female \\
\hline 20-24 y.o. & 208 & 204 & 210 & 196 \\
\hline 25-29 y.o. & 197 & 191 & 202 & 192 \\
\hline Total & 405 & 395 & 412 & 388 \\
\hline
\end{tabular}

Source: own research;

\subsection{Data collection}

The data collection in the qualitative study was performed through face-to-face in-depth interviews based on a study guide referring to motivation to return to a destination. Thus, each respondent was asked to choose from the 33 motivational variables compiled from literature and presented in Table 2 the variables that are important when considering returning to a destination. Also, the respondents were given the option of expressing their thoughts about the presented variables and to mention new variables. 
The data collection in the quantitative study was accomplished through administering questionnaires in 3 shopping malls in Bucharest and Cape Town designed using semantic differential scales for the motivational variables delineated in the qualitative study.

Table 2. Motivational factors used in the research

\begin{tabular}{|c|c|c|}
\hline $\begin{array}{l}\text { Motivational factor- collected from the literature } \\
\text { and own qualitative research }\end{array}$ & $\begin{array}{l}\text { Source (selected or } \\
\text { adapted from) }\end{array}$ & $\begin{array}{l}\text { Retained / added for } \\
\text { quantitative research }\end{array}$ \\
\hline Encounter new life experiences & Crompton, 1979 & YES \\
\hline Escaping from a perceived mundane environment & Crompton, 1979 & \\
\hline Relaxation & Crompton, 1979 & \\
\hline Social interaction & Crompton, 1979 & \\
\hline Stimulation & Kim, 1997 & \\
\hline Fulfilment & Kim, 1997 & \\
\hline Self-esteem & Kim, 1997 & \\
\hline Health and fitness & Uysal and Hagan, 1993 & \\
\hline Adventure & Uysal and Hagan, 1993 & \\
\hline Having fun/entertainment & Li et al., 2013 & YES \\
\hline Having religious experiences & Pratminingsih et al., 2014 & YES \\
\hline Emotional identification & Shenna, 2014 & \\
\hline Accessibility of the destination & Embacher and Buttle, 1989 & YES \\
\hline Personal values & Pratminingsih et al., 2014 & \\
\hline $\begin{array}{l}\text { Being able to spend more time with friends and } \\
\text { family }\end{array}$ & Uysal and Hagan, 1993 & YES \\
\hline Proximity of the destination & Huang and Tsai, 2003 & YES \\
\hline Scenery & Uysal and Hagan, 1993 & \\
\hline $\begin{array}{l}\text { Well-developed superstructure (airports, attractions, } \\
\text { hotels) }\end{array}$ & $\begin{array}{l}\text { Tang and Rochananond, } \\
1990\end{array}$ & YES \\
\hline Good weather conditions & Huang and Petrick, 2010 & YES \\
\hline Recreational opportunities & Uysal and Hagan, 1993 & \\
\hline Quality of food offerings & Chon, 1991 & YES \\
\hline Personal safety & Li et al., 2013 & YES \\
\hline Friendly service & Li et al., 2013 & \\
\hline Appropriate accommodation & Li et al., 2013 & YES \\
\hline Variety of attractions & Shenna, 2014 & YES \\
\hline Getting away from city life & Uysal and Hagan, 1993 & YES \\
\hline Excitement & Wong et al., 2013 & \\
\hline $\begin{array}{l}\text { Efficient public transport to get around the } \\
\text { destination }\end{array}$ & Li et al., 2013 & YES \\
\hline Engaging with other cultures and people & Uysal and Hagan, 1993 & YES \\
\hline Catering for niche markets & Wong et al., 2013 & \\
\hline Marketing of the destination & Shenna, 2014 & \\
\hline Value for money/affordability & Shenna, 2014 & YES \\
\hline Shopping & Wong et al., 2013 & YES \\
\hline Improve my knowledge about the foreign country & own qualitative study & \\
\hline Visit unseen places & own qualitative study & \\
\hline Meet up with other travellers with similar interests & own qualitative study & \\
\hline
\end{tabular}

Source: as mentioned in the table, and own research 


\section{Results and Discussion}

The qualitative study performed based on in-depth interviews rendered 20 common motivational variables (Table 2) for both samples which were used in the questionnaire to collect quantitative data.

The data analysis for the quantitative study was performed for each country, the two parts of the model being analysed and discussed distinctively. For each model section, the logistic regression assumptions were checked and briefly presented in a table for the entire model.

\subsection{Results and discussions for the Romanian model}

Regarding the intention to return to the foreign destination part, the model is statistically significant, Chi-square $=154.701, \mathrm{p}=0.000$, explaining $23.5 \%$ (Nagelkerke R Square) of the variance in the Intention to return and correctly classifying $70.0 \%$ of the cases. Based on forward, backward and enter logistic regression and a non-significant value of the Hosmer-Lemeshow test of goodness of fit, from the initially proposed 20 motivational variables and 5 demographic ones, the most comprehensive model was retained, including 7 motivational variables (Q9.3_cat-Encounter new life experiences, Q9.4_cat-Have fun/entertainment, Q9.15-Be able to spend more time with friends and family, Q9.20_catValue for money, Q9.1-Improve my knowledge about the foreign country, Q9.10-Good weather conditions and Q9.11-Quality of food offerings) and one demographic variable Q20-(Gender). The independent variables with no answers in at least one level of the semantic differential scale were transformed in categorical variables with two levels: 1important- comprising the important and very important levels and 2- Not importantcomprising the unimportant, not important at all and neutral levels). All these variables are statistically significant considering the sig values (less than 0.05 ) of the Wald test. Also, the non-significant value of the Hosmer-Lemeshow test $(\mathrm{p}=0,127)$ shows an adequate level of data fitting.

Table 3. Logistic regression- Intention to return to a foreign destination- Romania

\begin{tabular}{|c|c|c|c|c|c|c|c|c|c|}
\hline \multicolumn{10}{|c|}{ Variables in the Equation } \\
\hline & & \multirow[b]{2}{*}{ B } & \multirow[b]{2}{*}{ S.E. } & \multirow[b]{2}{*}{ Wald } & \multirow[b]{2}{*}{ df } & \multirow[b]{2}{*}{ Sig. } & \multirow[b]{2}{*}{$\operatorname{Exp}(B)$} & \multicolumn{2}{|c|}{ 95\% C.I. for $\operatorname{EXP}(B)$} \\
\hline & & & & & & & & Lower & Upper \\
\hline \multirow[t]{9}{*}{ Step $1^{\mathrm{a}}$} & Q9.3_cat & -.890 & .262 & 11.594 & 1 & .001 & .410 & .246 & .685 \\
\hline & Q9.4_cat & 2.312 & .260 & 79.353 & 1 & .000 & 10.095 & 6.070 & 16.789 \\
\hline & Q9.15_cat & .455 & .190 & 5.717 & 1 & .017 & 1.576 & 1.085 & 2.288 \\
\hline & Q9.20_cat & .759 & .233 & 10.630 & 1 & .001 & 2.137 & 1.354 & 3.373 \\
\hline & Q9.1 & .474 & .098 & 23.402 & 1 & .000 & 1.606 & 1.325 & 1.946 \\
\hline & Q9.10 & -.533 & .121 & 19.382 & 1 & .000 & .587 & .463 & .744 \\
\hline & Q9.11 & .274 & .100 & 7.423 & 1 & .006 & 1.315 & 1.080 & 1.601 \\
\hline & Q20 & -.418 & .176 & 5.671 & 1 & .017 & .658 & .466 & .929 \\
\hline & Constant & -2.402 & .558 & 18.540 & 1 & .000 & .091 & & \\
\hline
\end{tabular}


After running the assumptions' tests (Table 5), the final model includes 3 motivational variables, Q9.4_cat (Have fun/entertainment), Q9.20_cat (Value for money) and Q9.11 (Quality of food offerings) and 1 demographic variable, Q20 (Gender). Have fun/entertainment, with an odds ratio of 10.095, displays that an individual valuing entertainment is 10.095 times more likely to return to the destination. Value for money, with an odds ratio of 2.137, shows that an individual considering important the expenses incurred by travelling is 2.137 times more likely to return to the destination. Quality of food offerings, with an odds ratio of 1.315, shows that an increase of one unit on the 5-level semantic differential scale increases the odds of returning to the destination by a multiplicative factor of 1.315 . Gender, with an odds ratio of 0.658 , shows that women are 1.519 times more likely to return to the destination than men. In conclusion, the Romanian respondents will return to the destination mainly for entertainment and food corroborated with a good financial offer, women being more likely to wish to return. Based on the findings, hypothesis H1 was partially retained as two variables ('Quality of food offerings' and 'Value for money') displayed a direct relationship with the dependent variable, while 'Good weather conditions' was removed from the model for not meeting the assumptions and the rest of the 7 pull variables ('Accessibility of the destination', 'Proximity of the destination', 'Well-developed superstructure (airports, attractions, hotels)', 'Personal safety', 'Appropriate accommodation', 'Variety of attractions', 'Efficient public transport to get around the destination') were not included in the model and, thus, inferring no relationship with the dependent variable. Hypothesis $\mathrm{H} 2$ was partially retained as one variable ('Have fun/entertainment') displayed a direct relationship with the dependent variable, while 'Improve my knowledge about the foreign country' and 'Encounter new life experiences' were removed from the model for not meeting the assumptions and the rest of the 7 push variables ('Visit unseen places', 'Have religious experiences', 'Meet up with other travellers with similar interests', 'Be able to spend more time with friends and family', 'Shopping', 'To get away from the city life', 'Engage with other cultures and people') were not included in the model and, thus, inferring no relationship with the dependent variable. Hypothesis $\mathrm{H} 3$ was rejected as women were more likely to return to the destination than men and hypotheses $\mathrm{H} 4, \mathrm{H} 5, \mathrm{H} 16, \mathrm{H} 7$ were rejected as the respective variables were not included in the model and, thus, inferring no relationship with the dependent variable.

Referring to the overall holiday experience-intention to return to the foreign destination part, the model is statistically significant, Chi-square $=62.530, \mathrm{p}=0.000$, explaining $10.1 \%$ (Nagelkerke R Square) of the variance in the Intention to return and correctly classifying $65 \%$ of the cases. Having only one predictor, the Wald test is used for the goodness of fit of the model $(\mathrm{p}=0.000)$ and the statistical significance of the predictor.

Table 4. Logistic regression- Holiday experience at a foreign destinationIntention to return to the destination- Romania

\begin{tabular}{|c|c|c|c|c|c|c|c|c|c|}
\hline \multicolumn{10}{|c|}{ Variables in the Equation } \\
\hline & & \multirow[b]{2}{*}{ B } & \multirow[b]{2}{*}{ S.E. } & \multirow[b]{2}{*}{ Wald } & \multirow[b]{2}{*}{ df } & \multirow[b]{2}{*}{ Sig. } & \multirow[b]{2}{*}{$\operatorname{Exp}(B)$} & \multicolumn{2}{|c|}{ 95\% C.I. for EXP(B) } \\
\hline & & & & & & & & Lower & Upper \\
\hline \multirow[t]{2}{*}{ Step $1^{\mathrm{a}}$} & Q7.10 & 1.245 & .162 & 59.421 & 1 & .000 & 3.474 & 2.531 & 4.768 \\
\hline & Constant & -.632 & .135 & 21.890 & 1 & .000 & .532 & & \\
\hline
\end{tabular}

Source: own research (SPSS vers. 19) 
Based on the finding and following the assumption tests (Table 5), an increase of one unit on the 5-level semantic differential scale measuring the overall holiday experience increases the odds of returning to the destination by a multiplicative factor of 3.474 , leading to the retaining of hypothesis $\mathrm{H} 8$, as there is a direct relationship between the two variables.

Table 5. Logistic regression assumptions for the Romanian model

\begin{tabular}{|c|c|c|}
\hline $\begin{array}{c}\text { Assumptions } \\
\text { (according to Stoltzfus, 2011) }\end{array}$ & $\begin{array}{l}\text { Intention to return to the } \\
\text { foreign destination }\end{array}$ & $\begin{array}{l}\text { Holiday experience at a } \\
\text { foreign destination - } \\
\text { Intention to return to the } \\
\text { foreign destination }\end{array}$ \\
\hline $\begin{array}{l}\text { The errors should be independent } \\
\text { (Field, 2009) }\end{array}$ & Met & Met \\
\hline $\begin{array}{l}\text { Linear relationship between continuous } \\
\text { predictors and their logs- Box Tidwell } \\
\text { test (Wuensch, 2014) }\end{array}$ & $\begin{array}{l}\text { Removal of Q9.1 (Improve } \\
\text { my knowledge about the } \\
\text { foreign country) and Q9.10 } \\
\text { (Good weather conditions)- } \\
\mathrm{p}<0.05\end{array}$ & $\begin{array}{l}\text { Not applicable (as only } \\
\text { predictor used) }\end{array}$ \\
\hline $\begin{array}{l}\text { Absence of multicollinearity- Variance } \\
\text { Inflation Factors for continuous } \\
\text { variables (Menard, 2002) and Phi } \\
\text { coefficient for categorical variables } \\
\text { (Muir et al., 2010) }\end{array}$ & $\begin{array}{l}\text { Removal of Q9.3_cat } \\
\text { (Encounter new life } \\
\text { experiences) and Q9.15_cat } \\
\text { (Be able to spend more time } \\
\text { with friends and family)- } \\
\text { because Phi }>0.30\end{array}$ & $\begin{array}{l}\text { Not applicable (as only } \\
\text { predictor used) }\end{array}$ \\
\hline $\begin{array}{l}\text { Strongly Influential Outliers- } \\
\text { Standardised/Studentised Residuals, } \\
\text { Cook's distances, Average Leverage, } \\
\text { DfBeta values for continuous variables } \\
\text { (Field, 2009) and Scatter Plots for } \\
\text { categorical variables (Friendly, 2000) }\end{array}$ & Met & $\begin{array}{l}\text { Not applicable (as only } \\
\text { predictor used) }\end{array}$ \\
\hline $\begin{array}{l}\text { Sample size- 10-15 events per } \\
\text { predictor (Babyak, 2004; Peduzzi et } \\
\text { al., 1996; Peduzzi et al., 1995) }\end{array}$ & $\begin{array}{l}\text { Met (446-Yes answers/354- } \\
\text { No answers) }\end{array}$ & $\begin{array}{l}\text { Met (558-satisfied } \\
\text { respondents/242- dissatisfied } \\
\text { respondents) }\end{array}$ \\
\hline
\end{tabular}

Source: own research (SPSS vers. 19)

\subsection{Results and discussions for the South African model}

The intention to return to the foreign destination part of the model is statistically significant, Chi-square $=98.834(\mathrm{p}=0.000)$, explaining 15.5\% (Nagelkerke R Square) of the variance in Intention to return and correctly classifying $62.5 \%$ of the cases. Based on forward, backward and enter logistic regression, the most comprehensive model was retained including 4 motivational variables out of the 20 initial ones and 1 demographic variable out of the 5 initial ones. All these variables (Q9.2-Visit unseen places; Q9.6-Meet up with other travellers with similar interests; Q9.9-Well-developed superstructure (airports, attractions, hotels), Q9.10-Good weather conditions and Q20-Gender) recorded a significant Wald test and the Hosmer and Lemeshow test rendered a non-significant value, thus the model showing an adequate level of data fitting. 
Table 6. Logistic regression-Intention to return to a foreign destination South Africa

\begin{tabular}{|c|c|c|c|c|c|c|c|c|c|}
\hline \multicolumn{10}{|c|}{ Variables in the Equation } \\
\hline & & \multirow[b]{2}{*}{ B } & \multirow[b]{2}{*}{ S.E. } & \multirow[b]{2}{*}{ Wald } & \multirow[b]{2}{*}{ df } & \multirow[b]{2}{*}{ Sig. } & \multirow[b]{2}{*}{$\operatorname{Exp}(B)$} & \multicolumn{2}{|c|}{$95 \%$ C.I. for $\operatorname{EXP}(B)$} \\
\hline & & & & & & & & Lower & Upper \\
\hline \multirow[t]{6}{*}{ Step $1^{\mathrm{a}}$} & Q9.2 & .484 & .107 & 20.309 & 1 & .000 & 1.623 & 1.315 & 2.003 \\
\hline & Q9.6 & .392 & .068 & 32.911 & 1 & .000 & 1.479 & 1.294 & 1.691 \\
\hline & Q9.9 & .183 & .080 & 5.224 & 1 & .022 & 1.200 & 1.026 & 1.404 \\
\hline & Q9.10 & .152 & .076 & 4.019 & 1 & .045 & 1.164 & 1.003 & 1.350 \\
\hline & Q20 & .480 & .153 & 9.792 & 1 & .002 & 1.616 & 1.196 & 2.182 \\
\hline & Constant & -4.794 & .642 & 55.740 & 1 & .000 & .008 & & \\
\hline
\end{tabular}

Based on the assumptions (Table 8), the final model comprises 3 motivational variables (Q9.2-Visit unseen places; Q9.9-Well-developed superstructure (airports, attractions, hotels), Q9.10-Good weather conditions) and one demographic variable (Q20-Gender). Visit unseen places, with an odds ratio of 1.623, displays that an increase with one level on the 5-level semantic differential scale increases the odds of returning to the destination by 1.623 times. Well-developed superstructure, with an odds ratio of 1.200 , shows that an increase of one level on the 5-level semantic differential scale increases the odds of returning by 1.200 times. Good weather conditions, with an odds ratio of 1.164 , shows that an increase of one level on the 5-level semantic differential scale increases the odds of returning by 1.164 times. Gender, with an odds ratio of 1.616 , renders that men are 1.616 times more likely than women to return to the destination. In conclusion, the South African respondents are likely to return to the destination mainly to visit unseen places and for good infrastructure and nice weather, men being more likely to return than women. Based on the findings, hypothesis H1 was partially retained as two variables ('Well-developed superstructure (airports, attractions, hotels)' and 'Good weather conditions') displayed a direct relationship with the dependent variable, while the rest of the 8 pull variables ('Accessibility of the destination', 'Proximity of the destination', 'Quality of food offerings', 'Personal safety', 'Appropriate accommodation', 'Variety of attractions', 'Efficient public transport to get around the destination' and 'Value for money') were not included in the model and, thus, inferring no relationship with the dependent variable. Hypothesis H2 was partially retained as one variable ('Visit unseen places') displayed a direct relationship with the dependent variable, while 'Meet up with other travellers with similar interests' was removed from the model for not meeting the assumptions and the remaining 8 push variables ('Improve my knowledge about the foreign country', 'Encounter new life experiences', 'Have fun/entertainment', 'Have religious experiences', 'Be able to spend more time with friends and family', 'Shopping', 'To get away from the city life', 'Engage with other cultures and people') were not included in the model and, thus, inferring no relationship with the dependent variable. Hypothesis H3 was retained as men were more likely to return to the destination than women and hypotheses H4, H5, H6, $\mathrm{H} 7$ were rejected as the respective variables were not included in the model and, thus, inferring no relationship with the dependent variable.

Related to the overall holiday experience-intention to return to the foreign destination part, the model is statistically significant, Chi-square $=73.825, \mathrm{p}=0.000$, explaining $11.8 \%$ (Nagelkerke R Square) of the variance in the Intention to return and correctly classifying 
$65 \%$ of the cases. Based on the Wald test in this case, the model shows an adequate level of data fitting and the predictor contributes to the explaining of the dependent variable.

Table 7. Logistic regression- Holiday experience at a foreign destination Intention to return to the foreign destination - South Africa

\begin{tabular}{|c|c|c|c|c|c|c|c|c|c|}
\hline \multicolumn{10}{|c|}{ Variables in the Equation } \\
\hline & & \multirow[b]{2}{*}{ B } & \multirow[b]{2}{*}{ S.E. } & \multirow[b]{2}{*}{ Wald } & \multirow[b]{2}{*}{ df } & \multirow[b]{2}{*}{ Sig. } & \multirow[b]{2}{*}{$\operatorname{Exp}(B)$} & \multicolumn{2}{|c|}{ 95\% C.I. for $\operatorname{EXP}(B)$} \\
\hline & & & & & & & & Lower & Upper \\
\hline \multirow[t]{2}{*}{ Step $1^{\mathrm{a}}$} & Q7.10 & 1.438 & .175 & 67.173 & 1 & .000 & 4.212 & 2.986 & 5.941 \\
\hline & Constant & -.940 & .154 & 37.465 & 1 & .000 & .391 & & \\
\hline
\end{tabular}

Source: own research (SPSS vers. 19)

Following the assumption tests (Table 8), the finding shows that an increase with one unit on the 5-level semantic differential scale measuring the overall holiday experience increases the odds of returning to the destination by a multiplicative factor of 4.212 , leading to the retaining of hypothesis $\mathrm{H} 8$, as there is a direct relationship between the two variables.

Table 8. Logistic regression assumptions for the South African model

\begin{tabular}{|c|c|c|}
\hline $\begin{array}{c}\text { Assumptions } \\
\text { (according to Stoltzfus, 2011) }\end{array}$ & $\begin{array}{l}\text { Intention to return to the } \\
\text { foreign destination }\end{array}$ & $\begin{array}{c}\text { Holiday experience at a } \\
\text { foreign destination - Intention } \\
\text { to return to the foreign } \\
\text { destination }\end{array}$ \\
\hline $\begin{array}{l}\text { The errors should be } \\
\text { independent (Field, 2009) }\end{array}$ & Met & Met \\
\hline $\begin{array}{l}\text { Linear relationship between } \\
\text { continuous predictors and their } \\
\text { logs- Box Tidwell test } \\
\text { (Wuensch, 2014) }\end{array}$ & $\begin{array}{l}\text { Removal of Q9.6 (Meet up with } \\
\text { other travellers with similar } \\
\text { interests)- for } \mathrm{p}<0.05\end{array}$ & $\begin{array}{l}\text { Not applicable (as only predictor } \\
\text { used) }\end{array}$ \\
\hline $\begin{array}{l}\text { Absence of multicollinearity- } \\
\text { Variance Inflation Factors for } \\
\text { continuous variables (Menard, } \\
\text { 2002) and Phi coefficient for } \\
\text { categorical variables (Muir et } \\
\text { al., 2010) }\end{array}$ & Met & $\begin{array}{l}\text { Not applicable (as only predictor } \\
\text { used) }\end{array}$ \\
\hline $\begin{array}{l}\text { Strongly Influential Outliers- } \\
\text { Standardised/Studentised } \\
\text { Residuals, Cook's distances, } \\
\text { Average Leverage, DfBeta } \\
\text { values for continuous variables } \\
\text { (Field, 2009) and Scatter Plots } \\
\text { for categorical variables } \\
\text { (Friendly, 2000) }\end{array}$ & Met & $\begin{array}{l}\text { Not applicable (as only predictor } \\
\text { used) }\end{array}$ \\
\hline $\begin{array}{l}\text { Sample size- 10-15 events per } \\
\text { predictor (Babyak, 2004; } \\
\text { Peduzzi et al., 1996; Peduzzi et } \\
\text { al., 1995) }\end{array}$ & $\begin{array}{l}\text { Met (426-Yes answers/374-No } \\
\text { answers) }\end{array}$ & $\begin{array}{l}\text { Met }(590-\text { satisfied } \\
\text { respondents/210-dissatisfied } \\
\text { respondents) }\end{array}$ \\
\hline
\end{tabular}

Source: own research 


\section{Managerial Implications}

This paper provides valuable information at least on two levels. First of all, the findings display what motivates individuals aged between 20 and 29 years old to revisit a foreign destination. The value of the findings is augmented by the dual perspective provided through the comparison between the Romanian and South African Generation Y samples. Managers can learn from this study what this age group seeks when choosing a tourism destination, differences occurring mainly due to cultural and value differences. This statement is in line with the work of Edu et al. (2014) in which difference pertaining to income distribution were uncovered between groups from South Africa and Romania. Also, based on the findings, managers at destinations can tailor their offers in such a way as to accommodate the motives underlying the return to the foreign destination.

Second of all, important managerial implications are drawn from the model proposed in this paper as the model can be applied as tested or tailored to distinct tourism destinations or tourist groups entailing fewer statistical restrictions than other methods, being easily usable following the methodology detailed in the paper. Amongst the main advantages of using this model are the less restrictive statistical assumptions and the possibilities of using data collected through non-parametric scales as well as transforming data collected using parametric scales into categorical data to be included in the model.

In conclusion, destination managers can make use of the model to understand their tourists' behaviour in order to build offers adapted to their peculiarities, while the findings of this study can shed light into what Romanian and South African individuals aged between 20 and 29 years old value and desire when choosing a foreign tourism destination.

\section{Research Limitations and Future Research Directions}

The first limitation of this research is that it does not focus on a particular destination but on the tourist behaviour of the two age layers of Generation $\mathrm{Y}$ when it comes to international travelling. The model applied to a particular destination using the same sample would probably render different findings, as each destination tries to position itself based on distinct features. Considering this thought, the model can be easily adjusted to the peculiarities of a destination.

The second limitation can be envisaged in the type of motivational variables used to predict the intention to return to the foreign destination. As a mixture of push and pull variables was used, although, as a result of a prior qualitative research, results might look differently if only motivational variables pertaining to the destination were used or, conversely, if only motivational factors pertaining to the individual were used. Of course, such approaches are ideas that can be pursued in future research. However, the predictors included in the model should be uncovered and tested in prior qualitative research (in-depth interviews or focus groups) run with individuals from the same sample and/or other parties involved in the tourism business (Kozak, 2001).

Overall, these findings should be treated with caution when it comes to Generation Y as they refer to two age layers, one between 20 and 24 years old and the other one between 25 and 29 years old and according to Paul (2001) should not be automatically extended to the 
entire Generation Y because of its heterogeneity. This model should be applied to the other age layers of Generation $Y$ for acquiring a comprehensive image of this generation.

\section{Conclusion}

The findings reveal that the Romanian Generation Y members between 20 and 29 years old tend to return to the foreign tourism destination for motives pertaining to entertainment and food but placed in a rational context as they mentioned value for money as a reason for returning. An interesting finding is that women are more likely to return to the foreign destination than men. Overall considered, a satisfying holiday experience is more likely to lead to the return to the foreign destination according to the findings. On the other hand, the South African Generation Y members between 20 and 29 years old are more likely to return to the foreign tourism destination because of rather rational motives, such as good infrastructure and weather, adding to these motives visiting unseen places. Interestingly, considering the sociodemographic perspective, men are more likely to return than women.

Also, the overall holiday experience, as in the case of the Romanian counterparts, has a direct relationship with the intention to return to the destination. These findings are understandable considering the cultural differences between the two groups confirming to a certain extent the consumer behaviour patterns unveiled by Edu et al. (2014). From another perspective, the differences reveal the versatility of the proposed model, making it a suitable tool to be replicated in other parts of the world for the same generational group.

\section{References:}

Allison, P.D. (2008). Convergence Failures in Logistic Regression, Proceedings of the SAS Global Forum 2008, SAS Institute Inc., Cary, NC, Paper 360.

Assaker, G., Vinzi, V.E. and O'Connor, P. (2011). Examining the effect of novelty seeking, satisfaction, and destination image on tourists' return pattern: A two factor, non-linear latent growth model, Tourism Management, 32: 890-901.

Babyak, A.M. (2004). What You See May Not Be What You Get: A Brief, Nontechnical Introduction to Overfitting in Regression-Type Models, Psychosomatic Medicine, 66: 411-421.

Baker, D.A. and Crompton, J.L., (2000). Quality, satisfaction and behavioral intentions, Annals of tourism research, 27(3): 785-804.

Benckendorff, P. and Moscardo, G. (2010). Understanding Generation-Y Tourists: Managing the Risk and Change Associated with a New Emerging Market, in: Benckendorff P., Moscardo G., Pendergast D. (eds.), Tourism and Generation Y, CAB International, Wallingford, 38-46.

Bolton, R.N., Parasuraman, A., Hoefnagels, A., Migchels, N., Kabadayi, S., Gruber, Th., Lovreiro, Y.K. and Solnet, D. (2013). Understanding Generation Y and their use of social media: a review and research agenda, Journal of Service Management, 24(3): 245-267.

Cant, M., Brink, A. and Brijball, S. (2009). Consumer Behaviour, Juta \& Co., Cape Town.

Chen, C-F. and Chen, F-S. (2010). Experience quality, perceived value, satisfaction and behavioral intentions for heritage tourists, Tourism Management, 31: 29-35.

Chen, C.F. and Tsai, D. (2007). How destination image and evaluative factors affect behavioral intentions?, Tourism management, 28(4): 1115-1122.

Chon, K.S. (1991). Tourism destination image modification process: Marketing implications, Tourism Management, 12(1): 68-72. 
Crompton, J.L. (1979). Motivation for Pleasure Vacation, Annals of Tourism Research, 1(1): 408425.

Dann, G. (1977). Anomie, ego-enhancement and tourism, Annals of Tourism Research, 4(4):184194.

Edu, T., Lotter, W.A., Negricea, I.C. and Avram, E.M. (2014). Current Cross-cultural Personal Financial Behaviour Coordinates: Evidence from Romania and South Africa with a Focus on Young and Educated Individuals, Transformations in Business and Economics, 13(2B32B):833-852.

Eisner, S.P. (2005). Managing Gen Y, SAM Advanced Management Journal, 70(4):4-15.

Embacher, J. and Buttle, F. (1989). A repertory grid analysis of Austria's image as a summer vacation destination, Journal of Travel Research, 28(3):3-23.

Erickson, T. (2008). Plugged In: The Generation Y Guide to Thriving at Work, Harvard Business Press, Boston.

Field, A. (2009). Discovering Statistics using SPSS, $3^{\text {rd }}$ Ed., Sage Pub., London

Foscht, T., Schloffer, J., Maloles, C. and Chia, S.L. (2009). Assessing the outcomes of Generation Y customers' loyalty, International Journal of Bank Marketing, 27(3):218-241.

Friendly, M. (2000). Visualising Categorical Data, SAS Institute Inc, Carry, NC .

Glover, P. (2010). Generation Y's Future Tourism Demand: Some Opportunities and Challenges, in Benckendorff P., Moscardo G., Pendergast D. (eds.), Tourism and Generation Y, CAB International, Wallingford, UK, 155-164.

Howe, N. and Strauss, W. (2000). Millennials Rising: The Next Greatest Generation. Vintage Books, NY.

Huang, Y.C. and Petrick, J.F. (2010). Generation Y's Travel Behaviours: a comparison with Baby Boomers and Generation X, in: Benckendorff P., Moscardo G., Pendergast D. (eds.), Tourism and Generation Y, CAB International, Wallingford, UK, 27-37.

Huang, L. and Tsai, H.T. (2003). The study of senior traveler behavior in Taiwan, Tourism Management, 24(5):561-574.

Hughes, A.M. (1995). Making a database pay off using recency, frequency, and monetary analysis, Journal of Database Marketing, 3(1):77-89.

Hurst, J.L. and Good, L.K. (2009). Generation Y and career choice: The impact of retail career perceptions, expectations and entitlement perceptions, Career Development International, 14(6):570-593.

Jang, S. and Feng, R. (2007). Temporal destination revisit intention: The effects of novelty seeking and Satisfaction, Tourism Management, 28:580-590.

Jorgensen, B. (2003). Baby boomers, Generation X and Gen Y, Foresight, 4(4):41-49.

Kim, E. (1997) Korean outbound tourism: Pre-visit expectations of Australia, Journal of Travel and Tourism Marketing, 6(11):11-19.

Kim, H., Xiang, Z. and Fesenmaier, D.R. (2015). Use of The Internet for Trip Planning: A Generational Analysis, Journal of Travel \& Tourism Marketing, 32(3):276-289.

Kozak, M. (2001). Repeaters' behaviour at two distinct destinations, Annals of Tourism Research, 28(3):784-807.

Kozak, M. (2002). Comparative analysis of tourist motivations by nationality and destinations, Tourism Management, 23(3):221-232.

Kozak, M. and Rimmington, M., (2000). Tourist satisfaction with Mallorca, Spain, as an off-season holiday destination, Journal of travel research, 38(3):260-269.

Latour, S.A. and Peat, N.C. (1979). Conceptual and methodological Issues in consumer satisfaction research, Ralph day, Bloomington Wilkie, W.L. (Eds.), Indiana University Press, 31-35. 
Lehto, X.Y., O'Leary, J.T. and Morrison, A.M. (2004). The effect of prior experience on vacation behavior, Annals of Tourism Research, 31(4):801-818.

Li, X., Li, X.R. and Hudson, S. (2013). The application of generational theory to tourism consumer behaviour: An American perspective, Tourism Management, 37:147-164

Machado, L.P. (2010). Does destination image influence the length of stay in a tourism destination?, Tourism Economics, 16(2):443-456.

McCrindle, M. (2003). Understanding Generation Y, Principal Matters, 55:28-31.

Menard, S. (2002). Applied Logistic Regression Analysis, $2^{\text {nd }}$ ed., California Sage Publication, Thousand Oaks.

Moutinho, L., (1987). Consumer behaviour in tourism, European journal of marketing, 21(10):544.

Muir, S.W., Berg, K., Chesworth, B., Klar, N. and Speechley, M. (2010). Balance Impairment as a Risk Factor for Falls in Community-Dwelling Older Adults Who Are High Functioning. A Prospective Study, Physical Therapy, 90(3):338-347.

Muskat, M., Muskat, B., Zehrer, A. and Johns, R. (2014). Generation Y: evaluating services experiences through mobile ethnography, Tourism Review, 68(3): 55-71.

National Institute of Statistics (2015), Romania in Figures-Stat Abstract, Available at: $<$ www.insse.ro/cms/files/publicatii/Romania_in_cifre_2015final.pdf $>$ accessed: May 10, 2015

Noble, S.M., Haytko, D.L. and Phillips, J. (2009). What drives college-age Generation Y consumers?, Journal of Business Research, 62: 617-628.

Nusair, K.K., Bilgihan, A. and Okumus, F. (2013). The role of online social network travel websites in creating social interaction for Gen Y travelers, International journal of tourism research, 15(5):458-472.

Oliver, R.L. (1980). A cognitive model of the antecedents and consequences of satisfaction decisions, Journal of Marketing Research, 17: 46-49.

Oliver, R.L. and Swan, J.E. (1989). Consumer perceptions of interpersonal equity and satisfaction in transactions: A field survey approach, Journal of Marketing, 53: 21-35.

Oppermann, M. (2000). Tourism destination loyalty, Journal of travel research, 39(1):78-84.

Parment, A. (2013), Generation Y vs. Baby Boomers: Shopping behaviour, buyer involvement and implications for retailing, Journal of Retailing and Consumer Studies, 20(2):189-199.

Paul, P. (2001). Getting Inside Gen Y, American Demographics, September $1^{\text {st. }}$

Pearce, P.L. and Coghlan, A. (2008). The dynamics behind volunteer tourism, Journeys of discovery in volunteer tourism: International case study perspectives, 130-143.

Peduzzi, P.N., Concato, J., Holford, T.R. and Feinstein, A.R. (1995). The importance of events per independent variable in multivariate analysis: accuracy and precision of regression estimates, Journal of Clinical Epidemiology, 48:1503-1510.

Peduzzi, P.N., Concato, J., Kemper, E., Holford, T.R. and Feinstein, A.R. (1996). A simulation study of the number of events per variable in logistic regression analysis, Journal of Clinical Epidemiology, 49:1373-1379.

Pendergast, D. (2010). Getting to know the Y Generation, in: Benckendorff P., Moscardo G., Pendergast D. (eds.), Tourism and Generation Y, CAB International, Wallingford, UK, 1-15.

Pratminingsih, S.A., Rudatin, C.A. and Rimanta, T. (2014). Roles of Motivation and Destination Image in Predicting Tourist Revisit Intention: A case of Bandung- Indonesia, International Journal of Innovation, Management and Technology, 5(1):19-24.

Ratten, V. and Tsiotsou, R. (2010). Future research directions in tourism marketing, Marketing intelligence \& planning, 28(4):533-544.

Richards, G. (2007). New Horizons II: The Young Independent Traveller, 2007. World Youth Student \& Educational Travel Confederation, Madrid. 
Sheahan, P. (2005). Generation Y: thriving (and surviving) with Generation Y at work, Hardie Grant Books, Prahran.

Shenna, M. (2014). Tourist Destination: Demand-Motivating Factors in Israel's Domestic Tourism, Journal of Tourism Challenges and Trends, VII(2): 66-86.

Sommer, K. and Trudy, S. (2006). Managing Generation Y: Stop resisting and start embracing the challenges Generation Y brings to the workplace, Human Resources Magazine, 51(5).

Spreng, R.A., MacKenzie, S.B. and Olshavsky, R.W. (1996), A reexamination of the determinants of consumer satisfaction, The Journal of Marketing, 15-32.

Stats SA (2014), Stats in Brief, available at <www.statssa.gov.za/publications/StatsInBrief/StatsInBrief2014.pdf>, accessed: May 5, 2015

Stoltzfus, J.C. (2011). Logistic Regression: A Brief Primer, Academic Emergency Medicine, 18: 1099-1104.

Strydom, J. (2004). Introduction to Marketing, $3^{\text {rd }}$ ed., Juta \& Co., Cape Town

Szamosi, L.T. (2006). Just what are tomorrow's SME employees looking for?, Education + Training, 48: 654-665.

Tang, C.S. and Rochananond (1990) Attractiveness as a tourist destination: A comparative study of Thailand and selected countries, Socio-Economic Planning Sciences, 24(3): 229-236.

Tse, D. K. and Wilton, P.C. (1988), Models of consumer satisfaction: An extension, Journal of Marketing Research, 25: 204-212.

Uysal, M. and Hagan, L.A.R. (1993). Motivation of pleasure travel and tourism, in Khan, M., Olsen, M. and Var, T. (Eds.), VNR's Encyclopedia of Hospitality and Tourism, Van Nostrand Reinhold, New York, 798-810.

Valle, P.O.D., Silva, J.A., Mendes, J. and Guerreiro, M. (2006). Tourist satisfaction and destination loyalty intention: a structural and categorical analysis, International Journal of Business Science and Applied Management, 1(1):25-44.

Weaver, P.A., McCleary, K.W., Lapisto, L. and Damonte, L.T. (1994). The relationship of destination selection attributes to psychological, behavioral and demographic variables, Journal of Hospitality \& Leisure Marketing, 2(2): 93-109.

Wong, M., Cheung, R. and Wan, C. (2013). A Study on Traveler Expectation, Motivation and Attitude, Contemporary Management Research, 9(2): 169-186.

Wuensch, K.L. (2014). Binary Logistic Regression with SPSS, retrieved from $<$ http://core.ecu.edu/psyc/wuenschk/MV/MultReg/Logistic-SPSS.pdf $>$, accessed December 15, 2015.

Xiang, Z., Magnini, V. and Fesenmaier, D.R. (2015), Information technology and consumer behavior in travel and tourism: Insights from travel planning using the Internet, Journal of Retailing and Consumer Services, 22: 244-249.

Yoon, Y. and Uysal, M. (2005). An examination of the effects of motivation and satisfaction on destination loyalty: a structural model, Tourism management, 26(1): 45-56.

Zimmer, Z., Brayley, R.E. and Searle, M.S. (1995). Whether to go and where to go: Identification of important influences on seniors' decisions to travel, Journal of travel research, 33(3): 3-10. 